\title{
Synthesis and chemical characterization of some transition metal complexes with a 6-acetyl-1,3,7-trimetyllumazine ligand
}

\author{
N. El Azzouzi ${ }^{*}$, Z. El Fadli ${ }^{1}$, M. R. Metni ${ }^{1}$ \\ 1. Laboratory of Applied Organic Chemistry, Faculty of Sciences, \\ University Abdelmalek Essaadi, Tetouan, Morocco
}

\section{Received 15Feb 2017, Revised 15Jun2017, Accepted 20 Jun 2017 \\ Keywords \\ $\checkmark$ Metalcomplexes; \\ $\checkmark$ Lumazine; \\ $\checkmark$ Pyridinylhydrazone; \\ N.ElAzzouzi el azzouzibila@yahoo.fr $+2120663136101$}

\begin{abstract}
In order to continue our studies in coordination chemistry with pteridine derivatives, ligand pyridinylhdrazone of 6-acetyl-1,3,7-trimetyllumazine (PZLMH) and its mononuclear $\mathrm{Cu}(\mathrm{II}), \mathrm{Ag}(\mathrm{I}), \mathrm{Cd}(\mathrm{II}), \mathrm{Hg}(\mathrm{II})$ and $\mathrm{Gd}(\mathrm{III})$ complexes have been synthesized. Ligand and metal complexes were characterized by elemental analyses, ${ }^{1} \mathrm{H}$ - and ${ }^{13} \mathrm{C}-\mathrm{NMR}$ and IR studies. The result ssuggest that the mononuclear complexes have a metal to ligand mole ratio of $1: 1$ and the metal ions are coordinated with the phenolic oxygen and imine nitrogen atoms.
\end{abstract}

\section{Introduction}

It is well known that the heterocyclic hydrazones have a great biological relevance, as these compounds constitute an important class of biologically active molecules which have attracted attention of medicinal chemists due to their wide ranging pharmacological properties and their potential application as antitumor, antineoplastic, antiviral and antiinflammatory agents [1-6].

Specifically on the antitumor activity of aroylhydrazones, it has been shown to possess significant inhibiting effect on DNA synthesis and cell growth in a number of human and rodent cell lines [7]. It has been postulated that inhibition is due to their ability to penetrate cell membranes and disrupt the intracellular metabolism of essential metal ions [8-9].The exact nature of such disruptions and the extent to which they may be exploited for therapeutic purposes require deeper studies because biological activities of many of these organic compounds are increased when they are administered as metal complexes [10], so several metal chelates have been used as antitumour agents [11-12].

A literature survey indicated that the scientists are mostly impressed by biochemical qualities of pteridines, and their derivatives which have attracted the attention from several points of view, since they are capable of simulating the reactivity of metal sites in several enzymes [13-16].

On the other hand, the pyridine ring itself is a part of many natural and synthetically prepared pharmaceuticals. In addition, the pyridine moiety plays a significant role in many biological processes like nicotinamide adenine dinucleotide phosphate NADP or vitamin B6 [17-18].Nowadays, the metal complexes of these heterocycles have recently been studied as models to mimic the reactivity of the metal site of some metalloenzymes and they carry out diverse biological functions, being present in a number of biological systems involving several biochemist reactions of physiological relevance [19-24].

Furthermore, the functionalized 6-acetyl-1,3,7-trimethyllumazine pro-ligand (lumazine:pteridine-2,4(1H,3H)dione) has been already used as a precursor compound to build some thiosemicarbazone and hydrazone hybrid coordinative systems [25-26]. Thus, this work is aimed to describe the synthesis and chemical characterization of a new pteridine derivative, the pyridinehydrazone of 6-acetyl-1,3,7-trimetyllumazine (PZLMH) (Figure.1) and a number of new metal complexes, with $\mathrm{Cu}(\mathrm{II}), \mathrm{Cd}(\mathrm{II}), \mathrm{Hg}(\mathrm{II}), \mathrm{Ag}(\mathrm{I})$ and $\mathrm{Gd}(\mathrm{III})$ metals, providing a detailed spectroscopic (IR, ${ }^{1} \mathrm{H}$ and $\left.{ }^{13} \mathrm{C}-\mathrm{NMR}\right)$. 


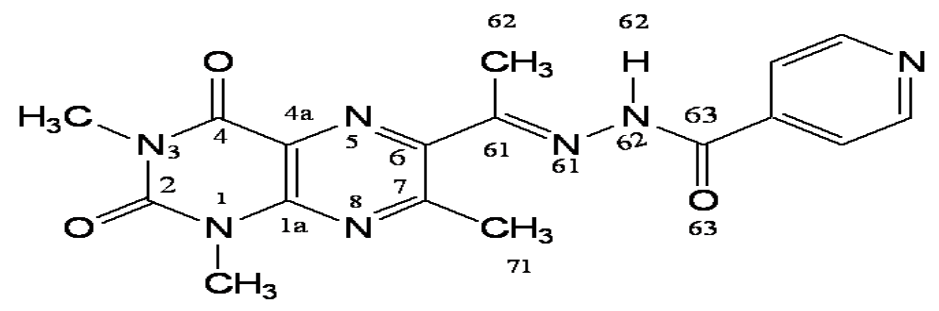

Figure 1:Numbering scheme for chemical structure of pyridinylhydrazone of 6-acetyl1,3,7-trimethyllumazine (PZLMH) (1).

\section{Experimental details}

\subsection{Measurements}

Elemental analyses were carried out with Thermo Finnigan Flash EA 1112. The IR spectra were performed between 4000 and $400 \mathrm{~cm}^{-1}$ using $\mathrm{KBr}$ pellets on a Bruker TGA-IR Tensor 27; the intensity of reported IR signals is defined as $\mathrm{s}=$ strong, $\mathrm{m}=$ medium, $\mathrm{w}=$ weak. ${ }^{1} \mathrm{H}$ and ${ }^{13} \mathrm{C}-\mathrm{NMR}$ spectra (DMSO-d6) were recorded on a BrukerAvance 400; the chemical shifts were referenced to residual solvent resonance external TMS (tetrameth-ylsilane) in the ${ }^{1} \mathrm{H}$ and ${ }^{13} \mathrm{C}$ spectra; the splitting of proton resonances in the reported ${ }^{1} \mathrm{H}$ NMR spectra is defined as $\mathrm{s}=$ singlet, $\mathrm{d}=$ doublet, and $\mathrm{m}=$ multiplet

\subsection{Materials}

Metallic nitrates and perchlorates were purchased from standard commercial sources. Reagent-grade solvents were used without further purification.

\subsection{Synthesis of compounds}

\subsubsection{Synthesis of pyridinylhydrazone of 6-acetyl-1,3,7-trimetyllumazine (PZLMH)(1)}

The pro-ligand 6-acetyl-1,3,7-trimethyllumazine (DLMACEM) was prepared by standard Timmis reaction between 6-amino-5-nitrosopyrimidines and 1,3-dicarbonylic derivatives by the method described by Kim et al [27]. The pyridinylhydrazone ligand (PZLMH) (1) was prepared by condensation of equimolar amounts of lumazine derivative (DLMACEM) $(2.5 \mathrm{~g}, 10 \mathrm{mmol})$ and pyridinylhydrazone $(1.4 \mathrm{~g}, 10 \mathrm{mmol})$ in ethanol $(30 \mathrm{~mL})$ with $0.5 \mathrm{~mL}$ of acetic acid used as catalyst (Figure.2).<smiles>Cn1c(N)c(N=O)c(=O)n(C)c1=O</smiles><smiles>CC(=O)CC(C)=O</smiles><smiles>CC(=O)c1cnc2c(n1)c(=O)n(C)c(=O)n2C</smiles>

DLMACEM

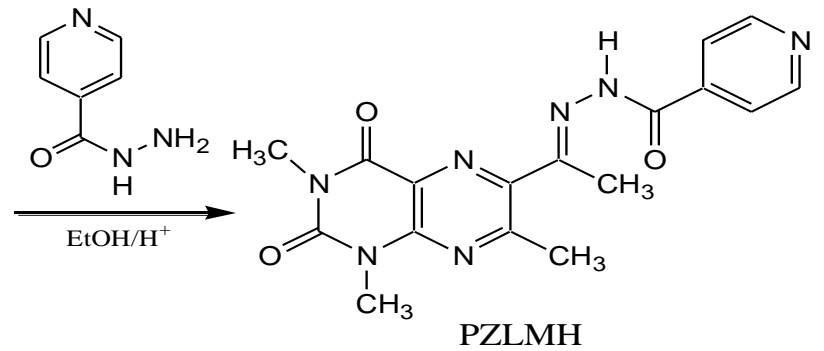

Figure 2:Synthesis of PZLMH ligand.

Themixturewasrefluxedfor3hat $80{ }^{\circ}$ Candthenwasleft tostandtoroomtemperature. The beige solidformed (3.02 g)inhighyield(82\%) wasfilteredandwashedwithethanoland diethylether.Elementalanalysisfound(\%), C,55.48; $\mathrm{H}$, 4.70; N,26.62.Calc. $\mathrm{ForC}_{17} \mathrm{H}_{17} \mathrm{~N}_{7} \mathrm{O}_{3}$ (367.47):C,55.58;H, 4.66;N,26.69. IR (KBr, cm $\left.{ }^{-1}\right): 3455,3331(\mathrm{~m}, v(\mathrm{~N}-$ $\mathrm{H})) ; 1711,1679,1656(\mathrm{vs}, v(\mathrm{C}=\mathrm{O})) ; 1587(\mathrm{w}, v(\mathrm{~N}=\mathrm{C}-\mathrm{CH} 3)) ; 1549(\mathrm{~m}, v(\mathrm{C}=\mathrm{N})) ; 1432,1288(\mathrm{~m}, v(\mathrm{C}=\mathrm{C})+v(\mathrm{C}-$ $\mathrm{N})$ ); $1024(\mathrm{w}, \mathrm{v}(\mathrm{N}-\mathrm{N})) .{ }^{1} \mathrm{HNMR}\left(\left(\mathrm{CD}_{3}\right)_{2} \mathrm{SO}, \mathrm{d}, \mathrm{ppm}\right): 2.47$ (s, C62-H); 2.93 (s, C71-H); 3.31 (s, N3-Me); 3.55 (s, N1-Me); 7.55, 8.44 (meta, Ph); 8.75, 9.05 (ortho, Ph); 11.0 (s, N62-H). ${ }^{13} \mathrm{CNMR}\left(\left(\mathrm{CD}_{3}\right)_{2} \mathrm{SO}, \mathrm{d}, \mathrm{ppm}\right): 14.9$ (C62); 25.63 (C71); 28.36 (C3); 28.87 (C1); 123.81 (C4A); 141.82 (C6); 123.40, 135.92 (C Carom $_{2}$; 144.55 (C61); 145.79 (C1A); 148.49 (C2); 150.49 (C7); 159.33 (C4).

\subsubsection{Synthesis of the complexes}

All complexes were prepared using the same method. They were obtained by reacting a suspension of ligand PZLMH $(1 / 4 \mathrm{mmol})$ with a solution of metallic salt $(1 / 4 \mathrm{mmol})$ in the ethanol. The reaction mixture was heated and stirred to about $60^{\circ}$ for several hours. The resulting solids obtained were filtered and washed with ethanol and diethyl ether. 
2.3.2.1. Compound $\mathrm{Ag}\left(\mathrm{NO}_{3}\right)(\mathrm{PZLMH}) .(2)$. (0.12 g) Yield, ca. $92 \%$.Elemental analysis found, C, 37.48 ; $\mathrm{H}$, 3.28 ; N, 20.66 ; Calc. for $\mathrm{AgC}_{17} \mathrm{H}_{17} \mathrm{~N}_{8} \mathrm{O}_{6}(537.34) \mathrm{C}, 37.99 ; \mathrm{H}, 3.19 ; \mathrm{N}, 20.85$. IR $\left(\mathrm{KBr}, \mathrm{cm}^{-1}\right): 3516$, $3332(\mathrm{~m}, v(\mathrm{~N}-\mathrm{H})) ; 1712,1659(\mathrm{~s}, \mathrm{v}(\mathrm{C}=\mathrm{O})) ; 1589\left(\mathrm{w}, v(\mathrm{C}=\mathrm{N})_{\text {azom }}\right) ; 1549(\mathrm{~m}, \mathrm{v}(\mathrm{C}=\mathrm{N})) ; 1473,1290(\mathrm{~m}$, $v(\mathrm{C}=\mathrm{C})+v(\mathrm{C}-\mathrm{N})) ; 1025(\mathrm{w}, v(\mathrm{~N}-\mathrm{N})) ; 1384\left(\mathrm{~m}, v(\mathrm{~N}-\mathrm{O})_{\text {nitrate }}\right)$.

2.3.2.2. Compound $\mathrm{Cd}\left(\mathrm{NO}_{3}\right)_{2}(\mathrm{PZLMH}) .(3)$. $(0.14 \mathrm{~g})$ Yield, ca. $92 \%$.Elemental analysis found, $\mathrm{C}, 37.75 ; \mathrm{H}$, $3.75 ; \mathrm{N}, 19.24$; Calc. for $\mathrm{CdC}_{17} \mathrm{H}_{17} \mathrm{~N}_{9} \mathrm{O}_{9}(603.88) \mathrm{C}, 33.82 ; \mathrm{H}, 2.84 ; \mathrm{N}, 20.24$. IR $\left(\mathrm{KBr}, \mathrm{cm}^{-1}\right): 3474$ $(\mathrm{m}, \mathrm{v}(\mathrm{N}-\mathrm{H})) ; 1720,1665(\mathrm{~s}, \mathrm{v}(\mathrm{C}=\mathrm{O})) ; 1599\left(\mathrm{w}, \mathrm{v}(\mathrm{C}=\mathrm{N})_{\mathrm{azom}}\right) ; 1556(\mathrm{~m}, \mathrm{v}(\mathrm{C}=\mathrm{N})) ; 1500,1298(\mathrm{~m}$, $v(\mathrm{C}=\mathrm{C})+\mathrm{m}(\mathrm{C}-\mathrm{N})) ; 1056(\mathrm{w}, \mathrm{v}(\mathrm{N}-\mathrm{N})) ; 1384\left(\mathrm{~m}, \mathrm{v}(\mathrm{N}-\mathrm{O})_{\text {nitrate }}\right)$.

2.3.2.3. 2.3.2.3. Compound $\mathrm{Hg}\left(\mathrm{ClO}_{4}\right)_{2}(\mathrm{PZLMH}) .(4)$. $(0.10 \mathrm{~g})$ Yield, ca. 52\%.Elemental analysis found, $\mathrm{C}$, $26.96 ; \mathrm{H}, 2.45 ; \mathrm{N}, 12.71$; Calc. for $\mathrm{HgC}_{17} \mathrm{H}_{17} \mathrm{~N}_{7} \mathrm{O}_{11} \mathrm{Cl}_{2}$ (766.96) C, $26.62 ; \mathrm{H}, 2.23$; N, 12.78. IR $\left(\mathrm{KBr}, \mathrm{cm}^{-1}\right): 3453(\mathrm{~m}, \mathrm{v}(\mathrm{N}-\mathrm{H})) ; 1718,1663(\mathrm{~s}, \mathrm{v}(\mathrm{C}=\mathrm{O})) ; 1580\left(\mathrm{w}, \mathrm{v}(\mathrm{C}=\mathrm{N})_{\text {azom }}\right) ; 1554(\mathrm{~m}, \mathrm{v}(\mathrm{C}=\mathrm{N}))$; 1504, $1292(\mathrm{~m}, \mathrm{v}(\mathrm{C}=\mathrm{C})+\mathrm{m}(\mathrm{C}-\mathrm{N})) ; 1121,1107,1088,627\left(\mathrm{~m}, \mathrm{v}(\mathrm{Cl}-\mathrm{O})_{\text {perchlorate }}\right)$.

2.3.2.4. Compound $\mathrm{Cu}\left(\mathrm{ClO}_{4}\right)_{2}(\mathrm{PZLMH}) .(5)$. $(0.082 \mathrm{~g})$ Yield, ca. $52 \%$.Elemental analysis found, $\mathrm{C}, 32.54 ; \mathrm{H}$, 2.68 ; N, 15.74 ; Calc. for $\mathrm{CuC}_{17} \mathrm{H}_{17} \mathrm{~N}_{7} \mathrm{O}_{11} \mathrm{Cl}_{2}(629.91) \mathrm{C}, 32.41 ; \mathrm{H}, 2.72 ; \mathrm{N}, 15.56$. IR $\left(\mathrm{KBr}, \mathrm{cm}^{-1}\right)$ : $3509(\mathrm{~m}, \mathrm{v}(\mathrm{N}-\mathrm{H})) ; 1720,1672(\mathrm{~s}, \mathrm{v}(\mathrm{C}=\mathrm{O})) ; 1574\left(\mathrm{w}, \mathrm{v}(\mathrm{C}=\mathrm{N})_{\text {azom }}\right) ; 1546(\mathrm{~m}, \mathrm{v}(\mathrm{C}=\mathrm{N})) ; 1519,1289$ $(\mathrm{m}, \mathrm{v}(\mathrm{C}=\mathrm{C})+\mathrm{m}(\mathrm{C}-\mathrm{N})) ; 1034(\mathrm{w}, \mathrm{v}(\mathrm{N}-\mathrm{N})) ; 1120,1108,1094,625\left(\mathrm{~m}, \mathrm{v}(\mathrm{Cl}-\mathrm{O})_{\text {perchlorate }}\right)$

2.3.2.5. 2.3.2.5. Compound $\mathrm{Gd}\left(\mathrm{NO}_{3}\right)_{3}(\mathrm{PZLMH}) .(\mathbf{6}) .(0.1 \mathrm{~g})$ Yield, ca. $58 \%$.Elemental analysis found, $\mathrm{C}, 27.50$ ; H, $2.43 ; \mathrm{N}, 19.16$; Calc. for $\mathrm{GdC}_{17} \mathrm{H}_{17} \mathrm{~N}_{10} \mathrm{O}_{12}(710.65) \mathrm{C}, 28.70 ; \mathrm{H}, 2.39 ; \mathrm{N}, 19.70 . \mathrm{IR}\left(\mathrm{KBr}, \mathrm{cm}^{-1}\right)$ : $3385(\mathrm{~m}, \mathrm{v}(\mathrm{N}-\mathrm{H})) ; 1718,1650(\mathrm{~s}, \mathrm{v}(\mathrm{C}=\mathrm{O})) ; 1580\left(\mathrm{w}, \mathrm{v}(\mathrm{C}=\mathrm{N})_{\text {azom }}\right) ; 1541(\mathrm{~m}, \mathrm{v}(\mathrm{C}=\mathrm{N})) ; 1474,1294$ $(\mathrm{m}, \mathrm{v}(\mathrm{C}=\mathrm{C})+\mathrm{m}(\mathrm{C}-\mathrm{N})) ; 1091(\mathrm{w}, \mathrm{v}(\mathrm{N}-\mathrm{N})) ; 1384\left(\mathrm{~m}, \mathrm{v}(\mathrm{N}-\mathrm{O})_{\text {nitrate }}\right)$.

\section{Results and discussion}

\subsection{Infrared Spectra}

IR data of the ligand and its complexes are given in table 1 and IR spectrum of ligand PZLMH it's represented in Figure 3. In the infrared spectrum of compounds, the bands about 3450 and $3330 \mathrm{~cm}^{-1}$ can be assigned to the vibration $v(\mathrm{~N}-\mathrm{H})$ of $\mathrm{N} 62$ hydrazonic $[28,29]$. Two sharp and intense bands must be assigned to the combination of the stretching vibrations of both exocyclic carbonyl groups, the first one assignable to the vibration $v(\mathrm{C} 2=\mathrm{O})$, while the second corresponds to the $v(\mathrm{C} 4=\mathrm{O})[28,29]$. In general, the $v(\mathrm{C} 63=\mathrm{O})$ mode can not be observed in the spectra of the complexes, because of the involvement in the coordination enlarges the bond shifting, consequently, the band to a lower wave-number region in which may be hidden by other lumazine vibrations; however the compounds $\mathrm{Cd}\left(\mathrm{NO}_{3}\right)_{2}(\mathrm{PZLMH})$ and $\mathrm{Gd}\left(\mathrm{NO}_{3}\right)_{2}(\mathrm{PZLMH})$ show a latter vibration $(v(\mathrm{C} 63=\mathrm{O}))$ displaced to 1644 and $1650 \mathrm{~cm}^{-1}$, respectively, which appearing as become a shoulder in the $v(\mathrm{C} 4=\mathrm{O})$ bands $[30,31]$.

Table 1.-Significant bands in the IR spectra of the ligand PZLMH and its metal complexes $\left(\mathrm{cm}^{-1}\right)$.

\begin{tabular}{|c|c|c|c|c|c|c|c|}
\hline Complexes & $v(\mathrm{~N}-\mathrm{H})$ & $v(C=O)$ & $v(C=N)_{\text {azom }}$ & $v(C=N)$ & $v(C=C)+v(C-N)$ & $v(\mathrm{~N}-\mathrm{N})$ & $\mathbf{v}(\mathbf{M}-\mathbf{X})$ \\
\hline PZLMH & $\begin{array}{l}3455 \\
3331\end{array}$ & $\begin{array}{l}1711 \\
1656\end{array}$ & 1587 & 1549 & $\begin{array}{l}1432 \\
1288\end{array}$ & 1024 & - \\
\hline $\mathrm{Ag}\left(\mathrm{NO}_{3}\right)(\mathrm{PZLMH})$ & $\begin{array}{l}3516 \\
3332 \\
\end{array}$ & $\begin{array}{l}1712 \\
1659 \\
\end{array}$ & 1589 & 1549 & $\begin{array}{l}1473 \\
1290 \\
\end{array}$ & 1025 & 1384 \\
\hline $\mathrm{Cd}\left(\mathrm{NO}_{3}\right)_{2}(\mathrm{PZLMH})$ & $3474^{\mathrm{a}}$ & $\begin{array}{l}1720 \\
1665\end{array}$ & 1599 & 1556 & $\begin{array}{l}1500 \\
1298\end{array}$ & 1056 & 1384 \\
\hline $\mathrm{Hg}\left(\mathrm{ClO}_{4}\right)_{2}(\mathrm{PZLMH})$ & 3453 & $\begin{array}{l}1718 \\
1663 \\
\end{array}$ & 1580 & 1554 & $\begin{array}{l}1504 \\
1292 \\
\end{array}$ & - & $\begin{array}{c}1121,1107 \\
1088,627\end{array}$ \\
\hline $\mathrm{Cu}\left(\mathrm{ClO}_{4}\right)_{2}(\mathrm{PZLMH})$ & 3509 & $\begin{array}{l}1720 \\
1672\end{array}$ & 1574 & 1546 & $\begin{array}{l}1519 \\
1289\end{array}$ & 1034 & $\begin{array}{c}1120,1108 \\
1094,625\end{array}$ \\
\hline $\mathrm{Gd}\left(\mathrm{NO}_{3}\right)_{3}(\mathrm{PZLMH})$ & 3385 & $\begin{array}{l}1718 \\
1650\end{array}$ & 1580 & 1541 & $\begin{array}{l}1474 \\
1294\end{array}$ & 1091 & 1384 \\
\hline
\end{tabular}

The azomethine mode tension $v(\mathrm{C}=\mathrm{N})$ appears between 1570 and $1620 \mathrm{~cm}^{-1}$, as found in literature [32, 33]. This band is weak or medium intensity infrared. Although often suffer displacement in both $\left(10-30 \mathrm{~cm}^{-1}\right)$ as a result of the N5 and N61 coordination of the metal ion in some compounds remains virtually unchanged.

Below they can also be found other modes of vibration including atoms which may potentially act as donors, such as $v(\mathrm{C}=\mathrm{C})$, strongly coupled with $v(\mathrm{C}-\mathrm{N})$. This coupling results in two bands that are around 1450 and $1290 \mathrm{~cm}^{-1}$, approximately, and corresponds to vibrations ring lumazine that involving primarily to nitrogen atoms N5 and N8 as well as carbon atoms C6 and C7. In general, a displacement is observed at higher wave 
number of these bands respect to its position in the spectrum of the free ligand, possibly due to coordination of N5. The vibration tension N-N of the hydrazone appears as a much weaker band.

The vibrations $v(\mathrm{~N}-\mathrm{O})$ own of nitrate groups are appearing located about $1384 \mathrm{~cm}^{-1}$ and corresponds, in all cases, with a very sharp band in the spectrum, suggest the presence of ionic nitrate in the complexes [34]. The vibration mode of the perchlorate ion, $v(\mathrm{Cl}-\mathrm{O})$, it appears split into two or three bands between 1080 and $1120 \mathrm{~cm}^{-1}$, splitting that is produced as a result of loss of $\mathrm{T}_{\mathrm{d}}$ geometry presenting the free perchlorate ions; moreover, the appearance in all cases of another band around $625-627 \mathrm{~cm}^{-1}$ assignable to the deformation $\delta(\mathrm{O}-$ $\mathrm{Cl}-\mathrm{O})$, is indicative of the presence of uncoordinated perchlorate ions [29, 35].

PZLMIH

FTIR TENSOR 27

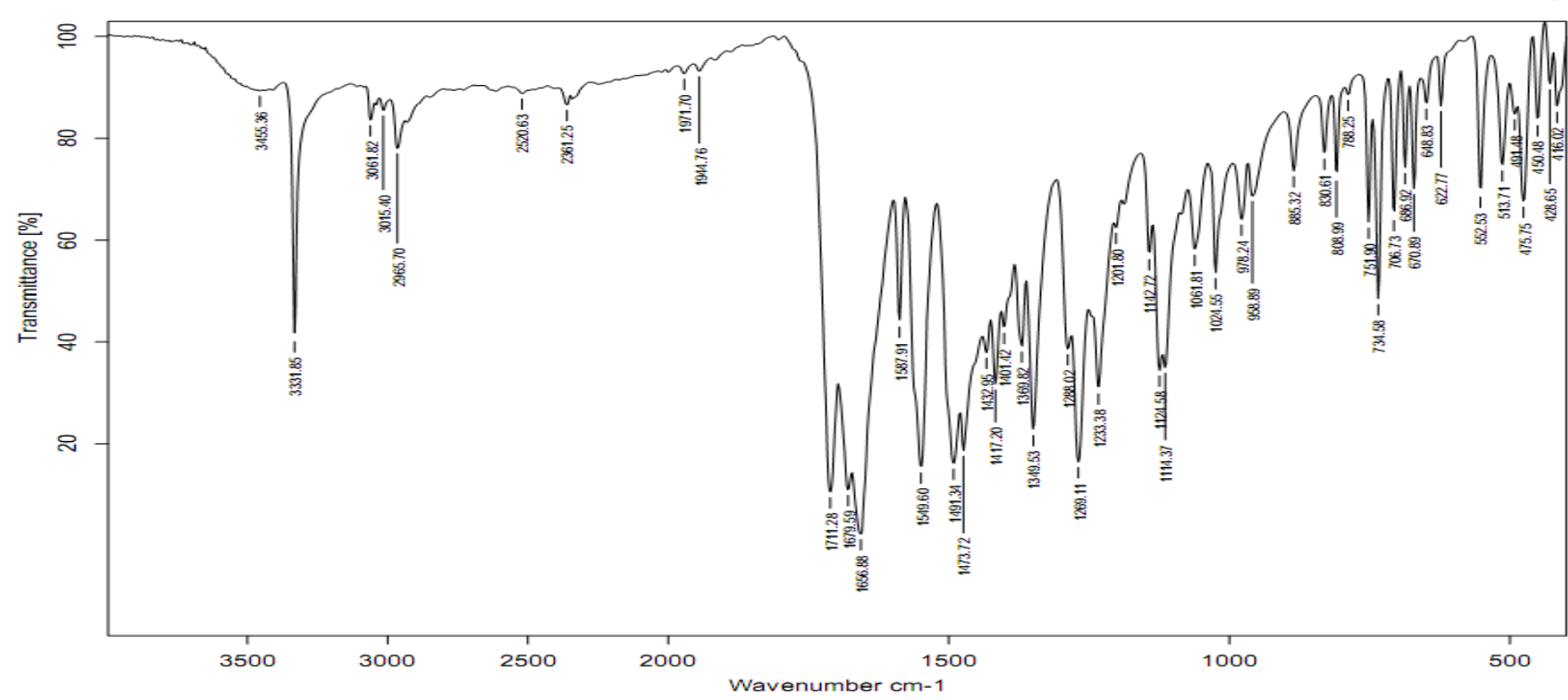

Figure 3:Infrared spectrum of ligand PZLMH.

\section{2. ${ }^{1} H$-NMR and ${ }^{13} C$-NMR Spectra}

The ${ }^{1}$ H-NMR spectra of the ligandwas recorded in dimethylsulfoxide (DMSO-d6) solution using tetramethylsilane (TMS) as internal standard. The ${ }^{1} \mathrm{H}-\mathrm{NMR}$ spectrum of (1) shows a singlet at 2.47 and 2.93 ppm that may be assigned respectively to the protons of $\mathrm{C} 62-\mathrm{H}$ and $\mathrm{C} 71-\mathrm{H}$. Authors singlets at 3.31 and 3.55 ppm that may be assigned to the proton of N3-Me and N1-Me, a signals between 7.55 and $9.05 \mathrm{ppm}$ may be assigned to the aromatic protons (Figure 4).

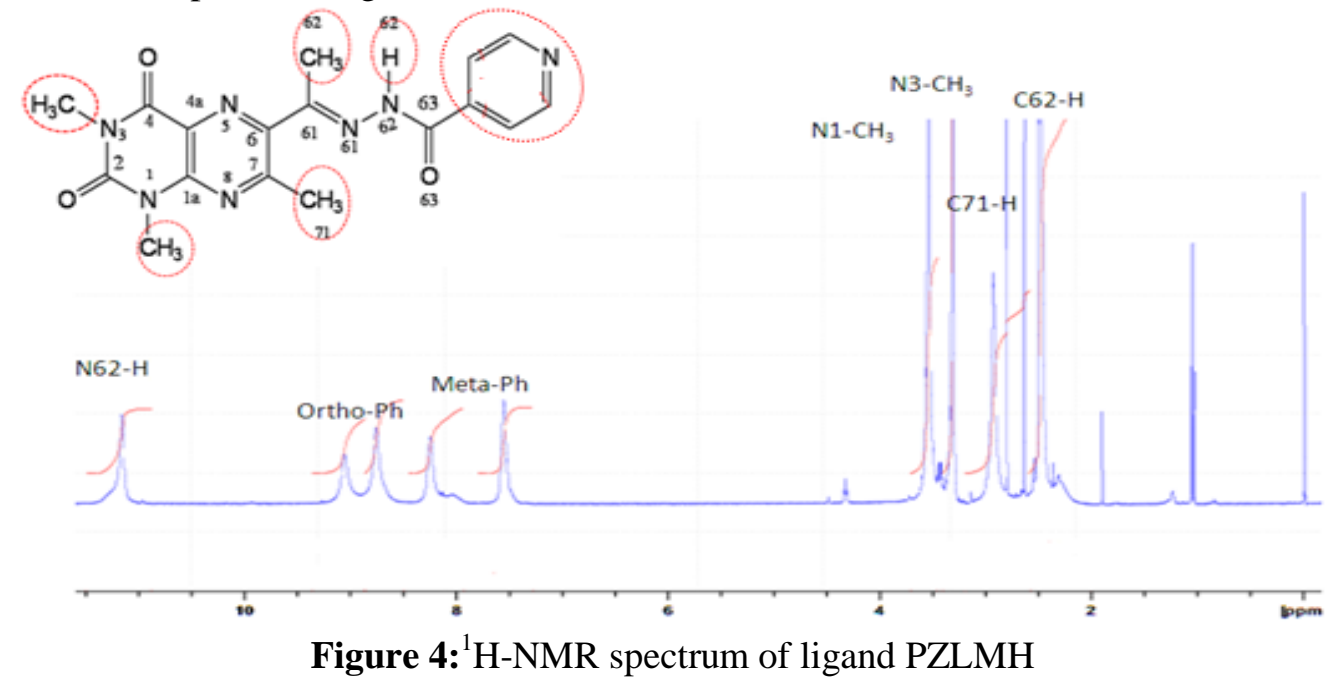

The ${ }^{13} \mathrm{C}$-NMR of the ligand (1) shows peaks at range 123.40-159.33 ppm, which are assignable to the carbons of the aromatic rings. The chemical shift for $\mathrm{C} 3$ and $\mathrm{C} 1$ was found at 28.36 and 28.87 respectively. The carbon atom of the methyl group was observed for $\mathrm{C} 62$ and $\mathrm{C} 71$ at 14.9 and 25.63 respectively. ${ }^{1} \mathrm{H}-$ and ${ }^{13} \mathrm{C}-\mathrm{NMR}$ spectra data of the ligand in DMSO-d6 confirm the proposed structure of the ligand (1) (Figure 5). 
Single crystals of the complexes could not be isolated from any solutions, thus no definite structure could be described. However, according toliterature [25-26, 29], there results and discussed through different techniques suggest below the proposed the possible coordination for behavior bidentate, tridentate and tetradentate ligand. shown in schema1-3.

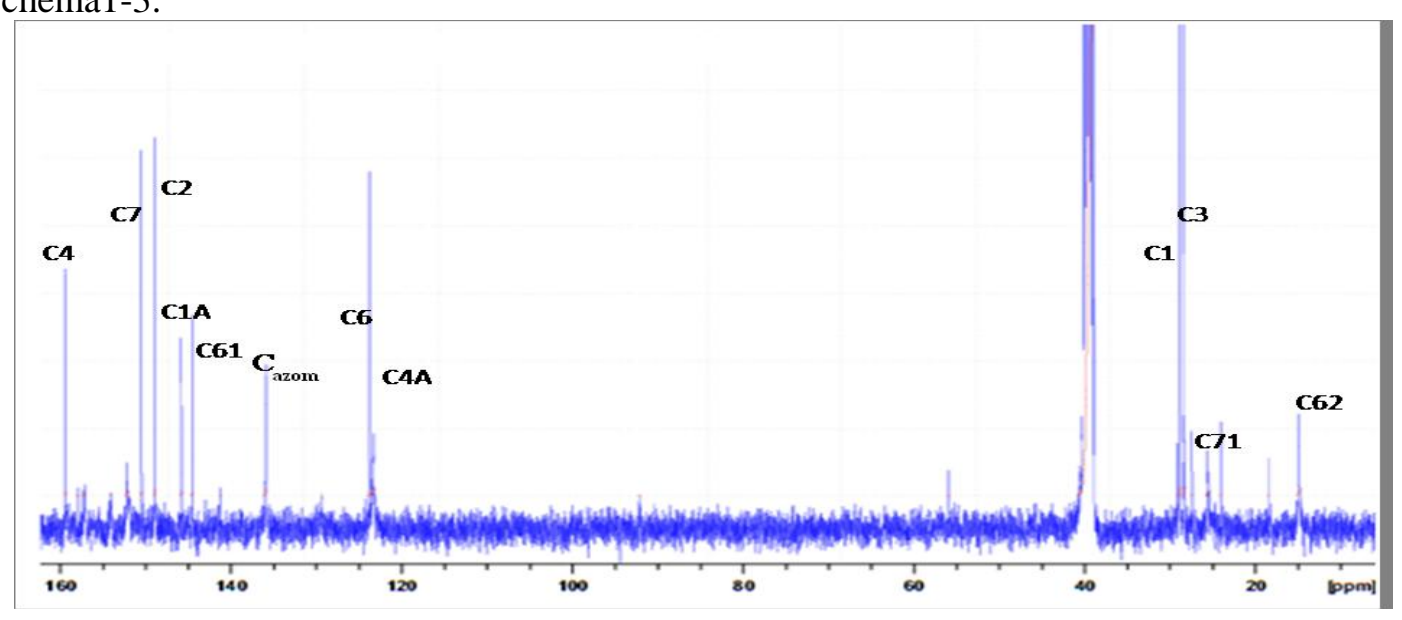

Figure 5: ${ }^{13} \mathrm{C}-\mathrm{NMR}$ spectrum of ligand PZLMH

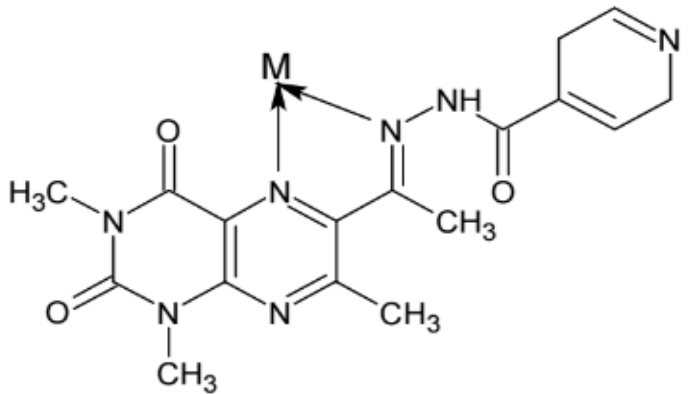

Scheme 1: Possible scheme of coordination for bidentate ligand PZLMH behavior.<smiles></smiles>

Scheme 2: Possible scheme of coordination for tridentate ligand PZLMH behavior.<smiles></smiles>

Scheme 3: Possible scheme of coordination for the complexes with a ligand bound to the metal tetradentate manner

\section{Conclusions}

In this paper, we reported the preparation, spectral identification, analytical data and coordination chemistry of pyridinylhydrazone of 6-acetyl-1,3,7-trimetyllumazine (PZLMH) derived from the pro-ligand 6-acetyl-1,3,7trimethyllumazine (DLMACEM) by condensation and its metal complexes with $\mathrm{Cu}$ (II), $\mathrm{Cd}(\mathrm{II}), \mathrm{Hg}(\mathrm{II}), \mathrm{Ag}$ (I) and Gd(III) metals ions.

Acknowledgments - The authors are pleased to acknowledge Professors Miguel N.MorenoCarretero, FransciscoHueso-Ureña and everyone in inorganic chemistry laboratory and technical service of the Faculty of Experimental Sciences, University of Jaén (Spain) for their contribution to this work, their constant availability and facilities granted. 


\section{References}

1. Petering H.G., Buskirk H.H., Crim J.A., CancerRes. 27 (1967) 1115.

2. Sartorelli A.C., Agrawal K.C., Tsiftsoglou A.S., Moore E.C., Adv. Enzyme Regul. 15 (1977) 117.

3. White J., Biochem. Biophys. Res. Commun. 77 (1977) 387.

4. Gianni L., Corden B.J., Myers C.E., The biochemical basis of anthracycline toxicity and antitumor activity, in: E. Hodgson, J.R. Bend, R.M. Philpot (Eds.), Reviews in Biochemical Toxicology, vol.5, Elsevier, NewYork, 1983, pp. 1-28.

5. Huang Z., May P.M., Quinlan K.M., Williams D.R., Creighton A.M., Agents Actions. 12 (1982) 536.

6. Howard R.A., Sherwood E., Erck A., Kimball A.P., Bear J.L., J. Med. Chem. 20 (1977) 943.

7. Johnson D.K., Murphy T.B., Rose N.J., Goodwin W.H., Pickart L., Inorg. Chim.Acta. 67 (1982) 159.

8. Pickart L., Goodwin W.H., Burgua W., Murphy T.B., Johnson D.K., Biochem. Pharmacol .32(1983) 3868.

9. Mohan M., Gupta N.S., Kumar A., Kumar M., Inorg. Chim. Acta. I35 (1987) 167.

10. Nawar N., Hosny N.M., Trans. Metal Chem. 25 (2000) 1.

11. Moore B. A, Moore E.C., Sartorelli A.C., Cancer Res. 31 (1971) 228.

12. Jhonson D.K., Murphy T.B., Rose N.J., Goodwin W.H., Pickart L., Inorg. Chim. Acta 67 (1982) 159.

13. Bertini I., H.B., Gray, Lippard S.J., Valentine J.S., Bioinorganic Chemistry. ISBN : 0-935702-57-1 (Print). University Science Books. Mill Valley, CA. 1994.

14. Chehlowski J., Coleman J.E., Met.Ions Biol. Chem. 6 (1985) 9.

15. Kaim W., Schewederski B., BioinorganicChemistry: Inorganic Elements in the Chemistry of Life. ISBN 10 : 0471943681 ISBN 13 : 9780471943686. Wiley. New York. 1994.

16. Farrell N., Transition Metal Complexes as Drugs and Chemotherapemic Agents, ISBN 10: 9401175705 ISBN 13 : 9789401175708 Kluwer. Boston, MA. 1989.

17. Lukevits E., Chemistry of heterocyclic compounds31(1995) 639.

18. Kapinos L.E., Sigel H., Inorg. Chim. Acta 337 (2002) 131.

19. Nixon J.C., Naturally occurring pterins, in: R.L. Blakley, S.J. Benkovic (Eds.), Folates and Pterins, vol. 2, John Wiley \& Sons, New York, 1984, pp.1-42.

20. Brown G.M., Biosynthesis of pterins, in: R.L. Blakley, S.J. Benkovic (Eds.), Folates and Pterins, vol. 2, John Wiley \& Sons, New York, 1984, pp. 115-154.

21. Murata S., Kiguchi K., Sugimoto T., Heterocycles 48 (1998) 1255.

22. Rieder J., Lirk P., Hoffmann G., Med. Hyp. 60 (2003) 531.

23. Wirleitner B., Obermoser G., Böck G., Neurauter G., Schennach H., Sepp N., Fuchsa D., Clin. Immunol. 107(2003) 152.

24. Schlemmer S.R., Sirotnack F.M., Biochem.Pharmacol.49 (1995) 1427.

25. Jiménez-Pulido S.B., Linares-Ordóñez F.M., Moreno-Carretero M.N., QuirósOlozábal M., Inorg. Chem. 47 (2008) 1096.

26. Jiménez-Pulido S.B., Linares-Ordóñez F.M., Martínez-Martos J.M., Moreno-Carretero M.N., QuirósOlozábal M., Ramírez-Expósito M.J., J.Inorg. Biochem.102 (2008) 1677.

27. Kim Y., Kim J., Kang Y., J. Korean Chem. Soc.43 (1999) 535.

28. Acuña-Cueva E.R., Faure R., Illán-Cabeza N.A., Jiménez-Pulido S.B., Moreno-Carretero M.N., QuirósOlozábal M., Inorg. Chim. Acta 351 (2003) 356.

29. Nakamoto K., Infrared Raman Spectra of Inorganic Coordination Compounds, fourthed, ISBN : 9780471743392 (Print) 9780470405840 (Online): Wiley, NewYork, 1997.

30. Das S., Pal S., J. Organomet. Chem. 689 (2004) 352-360.

31. Srinivasan S., Annaraj J., Athappan P. R., J. Inorg. Biochem. 99 (2005) 876.

32. Patole J., Sandbhor U., Padhye S., Deobagkar D.N., Anson Ch.E., Powell A.,Bioorganic and Medicinal Chemistry Letters. 13 (2003) 51.

33. Clere P., Simond S., Tablaspara la determinaciónestructuralpormétodosespectroscópicos, Ed. Springer, (1998).

34. Bhowon M.G., Wah H.L.K., Dosieah A., Ridana M., Ramalingum O.; Lacour D., Synth. React. Inorg. Met.34 (2004) 1.

35. Ferraro J.R., Low-Frecuency Vibrations of Inorganic and Coordination Compounds Plenum Press,New York, ISBN: 978-1-4684-1811-8 (Print) 978-1-4684-1809-5 (Online) (1971).

(2017) ; http://www.jmaterenvironsci.com 